\title{
Fish egg predation by Baltic sprat and herring: do species characteristics and
} development stage matter?

Neumann, Viola; Köster, Fritz; Eero, Margit

Published in:

Canadian Journal of Fisheries and Aquatic Sciences

Link to article, DOI:

10.1139/cjfas-2017-0105

Publication date:

2017

Document Version

Peer reviewed version

Link back to DTU Orbit

Citation $(A P A)$ :

Neumann, V., Köster, F., \& Eero, M. (2017). Fish egg predation by Baltic sprat and herring: do species characteristics and development stage matter? Canadian Journal of Fisheries and Aquatic Sciences, 75(10), 1626-1634. https://doi.org/10.1139/cjfas-2017-0105

\section{General rights}

Copyright and moral rights for the publications made accessible in the public portal are retained by the authors and/or other copyright owners and it is a condition of accessing publications that users recognise and abide by the legal requirements associated with these rights.

- Users may download and print one copy of any publication from the public portal for the purpose of private study or research.

- You may not further distribute the material or use it for any profit-making activity or commercial gain

- You may freely distribute the URL identifying the publication in the public portal 


\section{Fish egg predation by Baltic sprat and herring: do species characteristics and development stage matter?}

Viola Neumann ${ }^{1 *}$, Friedrich W Köster ${ }^{1}$, Margit Eero ${ }^{1}$

1. Technical University of Denmark, National Institute of Aquatic Resources, Kemitorvet, Bygning 202, 2800 Kgs. Lyngby, Denmark

e-mail:

F.W. Köster: fwk@aqua.dtu.dk

M. Eero: mee@aqua.dtu.dk,

* Corresponding author: ph.: (+ 45) 35883300 fax: (+ 45) 35883333

e-mail: vneu@aqua.dtu.dk

\section{Abstract}

Predation of eggs by clupeids has been identified as a major factor contributing to early life stage mortality of Baltic cod. We used data from ichthyoplankton sampling and clupeid stomach analyses to investigate whether eggs of other fish species are to a similar extent subject to predation, and how predation pressure differs between egg development stages. Cod, sprat and rockling eggs dominated in the ichthyoplankton fraction in herring and sprat diet, whereas flounder and dab eggs occurred only occasionally. In spring, cod eggs at advanced development stages were positively and sprat eggs generally negatively selected by both predators, while fish eggs were non-selectively consumed in summer. Predation is suggested to account for a large fraction of mortality of cod eggs at older stages, i.e. those eggs, which have survived the often detrimentally low oxygen concentration in and below the permanent halocline. The consumption rates of sprat eggs at all development stages relative to production rates were considerably lower compared to cod, suggesting that egg predation is of lesser importance for sprat recruitment. 
Keywords: prey selectivity, consumption, recruitment, fish eggs, egg development stages

\section{Introduction}

Predation on early life stages has been discussed as a major factor controlling recruitment success of marine fish stocks since decades (e.g. Hunter 1984; Sissenwine 1984). There is considerable evidence that predation by invertebrates and fish can be a major source of mortality of pelagic fish eggs and in some cases also of larvae (Heath 1992; Legett and DeBlois 1994; Hunter 1982; Brownell 1985). Predation pressure may be high especially in strongly stratified estuarine systems, where early life stages dwell in intermediate water layers utilized by pelagic fish for foraging, for example in the Central Baltic (Köster and Möllmann 2000a), the Black Sea (Prodanov et al. 1997) and the Gulf or St. Lawrence (Swain and Sinclair 2000). However, field studies quantifying the impact of predation are extremely difficult to design (Bailey and Houde 1989) and results are difficult to interpret due to uncertainties in the different factors involved, e.g. predator and prey abundance and fish egg consumption rate by individual predators (Heath 1992).

The Bornholm Basin, located in the central Baltic Sea, constitutes a small-scale "model" ecosystem with strong predator-prey interactions, top-down and bottom-up processes as well as feedback loops (e.g. Rudstam et al. 1994; Flinkman et al. 1998; Möllmann et al. 2000). Furthermore, it constitutes the single most important spawning area of the Eastern Baltic cod stock (e.g. Köster et al. 2017) and an important spawning area of sprat (e.g. Voss et al. 2012). Cod, sprat and herring are key components of the pelagic ecosystem in this area (e.g. Cardinale and Arrhenius 2000): cod being the main predator of the clupeids sprat and herring, while both of these planktivore species prey, amongst others, on cod early life stages (e.g. Köster and Möllmann 2000a), but also on other ichthyoplankton such as sprat and rockling eggs (Köster and Schnack 1994).

Previous studies have described the diet compositions of sprat and herring in the Baltic Sea (e.g. Möllmann et al. 2004,) including fish eggs and larvae (Karaseva et al. 2013). Also, consumption rates of cod eggs (Köster and Möllmann 2000a, Neumann et al. 2014) and prey selectivity focusing on zooplankton (e.g. Flinkman et al. 1992; Casini et al. 2004; 
Bernreuther et al. 2013) have been addressed. However, studies quantifying consumption of different development stages of eggs of different taxa are so far lacking.

A stage- rather than size selective predation on cod eggs is suggested for Baltic herring (Wieland and Köster 1996) and supported by findings in the Irish Sea, where sprat and herring consumed more plaice eggs in later stages of development (Ellis and Nash 1997; Segers et al. 2007). In the Baltic Sea, a preference for older egg stages would imply that the impact of egg predation on recruitment of cod (Köster and Möllmann 2000a; Neumann et al. 2017) and sprat (Köster and Möllmann 2000b) may be severe, if predation mortality is mainly acting on the egg stages, which have survived the often detrimental hydrographic conditions in the central Baltic Sea (Wieland et al. 1994).

In the present study, we investigate the selectivity of fish eggs from different taxa by clupeid predators, amongst others to validate the hypothesis whether the total abundance of fish eggs triggers egg predation as suggested by Köster and Möllmann (2000a), or whether eggs of specific taxa are actively selected from the ichthyoplankton prey field. Next, we verify whether the active selection of older egg stages, earlier reported for herring as a predator, also holds for sprat. Finally, we for the first time quantify stage specific predation pressure on cod and sprat eggs to elaborate on the importance of egg predation for early life stage survival and ultimately fish stock recruitment.

\section{Material and Methods}

\section{Data}

The key datasets used in this paper include i) fish egg abundances as prey, ii) diet compositions of herring and sprat as predators, iii) predator abundances and iv) hydrographic conditions within the Bornholm Basin defined by the $60 \mathrm{~m}$ depth contour (see also Fig. $\left.\mathrm{S}^{1}{ }^{1}\right)$. The material was derived from altogether 10 surveys, conducted in the Bornholm Basin in 2004-2008, in May/June (spring) and July/August (summer). Fish egg abundances and stomach contents of sprat and herring were sampled in locations shown in Fig. $S 1^{1}$ and $S 2^{1}$, respectively, with the number of stations given in Table 1 . The details on sampling gears, catching methods, and processing of samples are described in Neumann et al. (2014). The data and calculation procedures involved in deriving fish egg

\footnotetext{
${ }^{1} \mathrm{Fig} . \mathrm{S} 1$ and S2, showing locations of ichthyoplankton and trawl stations, are available in supplementary.
} 
consumption and production rates are described in Neumann et al. (2017). Thus, the material and methods section here focuses on describing the data and analyses specific to this paper, while for description of the data and analyses performed in early studies and further utilized in this paper, the reader is referred to these earlier investigations.

Availability of fish eggs in the prey field

Ichthyoplankton samples were collected with a Bongo-net with $335 \mu \mathrm{m}$ mesh size on a station grid of $10 \times 12.5 \mathrm{~nm}$ in the central Bornholm Basin in the Baltic Sea (see Neumann et al. 2017 for further details). The grid consisted of $\sim 45$ evenly spaced stations on which double-oblique Bongo hauls that sampled the entire water column down to ca $5 \mathrm{~m}$ above the seafloor were conducted. To obtain information on the vertical distribution of fish eggs, tows with a vertically resolving multinet (50 $\mu \mathrm{m}$ mesh size) were conducted on a central station of the grid. As density gradients define the depths where eggs dwell, and these density gradients do not change much within the basin (Wieland 1995), a station in the centre of the basin is considered representative of the stratification and abiotic environment of the deep parts of the basin and thereby vertical distribution of fish eggs. The collected samples from both gears were preserved in formaldehyde-seawater solution and later sorted and raised/standardized to obtain horizontal $\left(n^{*} m^{-2}\right)$ and vertical $\left(n^{*} m^{-3} ; 5\right.$ $\mathrm{m}$ bins) abundance and distribution from Bongo and multinet samples, respectively. Identification of developmental stage (Ia, Ib, II, III, IV) of fish eggs was based on Thompson and Riley (1981). Dead eggs were separated from viable eggs using the criteria given by Geldmacher and Wieland (1999).

\section{Fish eggs in clupeid diet}

Concurrent to the ichthyoplankton field sampling, trawl hauls targeting clupeid schools (when present) were conducted in the central Bornholm Basin. In consideration of diurnal vertical migration and feeding patterns of clupeids (e.g. Köster and Schnack 1994, Nilsson et al. 2003), only daytime (15 $\mathrm{min}$ after sunrise until $15 \mathrm{~min}$ before sunset) data were included. Most of the fish were sampled around or below the permanent halocline located at -55-70 $\mathrm{m}$ depth in the Bornholm Basin (Carstensen et al. 2014). The halocline separates low saline surface water from a denser layer with higher salinity, where pelagic fish concentrate during their daily feeding period (Köster and Schnack 1994). 
Clupeid stomachs were sampled applying a length-stratified sampling system. The stomachs were preserved in $4 \%$ borax-buffered formaldehyde seawater solution and later analysed in the lab. After fractioning stomach contents into major taxonomic groups and assessing their relative contribution, the ichthyoplankton components of the stomach contents were analysed in further detail, including determination of taxa and development stage. Stomach handling followed the procedures described by Köster (1994) and Köster and Schnack (1994) and data processing to obtain diet compositions is described in Neumann et al (2014).

\section{Data analyses}

\section{Selectivity}

Station and cruise specific abundances of fish eggs in the diet and in the prey field, by taxa and development stage, were calculated by allocating Bongo stations within a $6 \mathrm{~nm}$ radius from a trawl station as prey field. The $6 \mathrm{~nm}$ radius represents the highest spatial resolution possible within these data, as it is approximately half of the distance to the next ichthyoplankton sampling station, at the $10 \times 12.5 \mathrm{~nm}$ station grid allowing for a unique allocation of most fish sampling hauls to a specific ichthyoplankton station (Table $S 1^{2}$ ). The station-specific estimates for different taxa were subsequently averaged for each cruise, representing seasons and years.

Stations containing no fish eggs in the prey field and in the diet were eliminated. Further, the stomachs with only unidentified eggs were excluded from the analyses, which in some cases resulted in excluding entire stations and no data available for some years (e.g. for sprat in spring 2005 and 2008). This altogether led to a variable number of stations that were included in the selectivity analyses (see Fig. S2).

The log10 transformed Shorigin Index (Berg 1979) was applied to calculate a prey selectivity index (Sel) per prey category (Table $\mathrm{S} 1^{2}$ ),

$$
\text { Sel }=\log _{10} \frac{\% N_{i} \text { in the ingested food }}{\% N_{i} \text { in the potentially available food }}
$$

where $N_{i}$ is the numerical percentage of a given item (e.g. fish eggs of a specific taxa).

The prey selectivity indices obtained represent the selection of fish eggs of specific taxa and development stage from the ichthyoplankton prey field, not taking into account other

\footnotetext{
2 Table S1, showing station specific selectivity indices for cod, sprat and rockling eggs, are available in supplementary.
} 
prey components, such as zooplankton. The values for the selectivity indices were categorized into 5 groups: i) prey is strongly selected $(\geq 2.0)$, ii) prey is selected $(<2.0$ to 0.50 ), iii) non-selective feeding (<0.5 to $>-0.5)$, iv) prey is avoided $(-0.50$ to $<-2.0$ ) and $v$ ) prey is strongly avoided $(\leq-2.0)$. The occurrence of cases in the data where the prey was found in the diet but not in the prey field and vice versa, are represented by (+) and (-), respectively (Table S1; Table S2), but such cases were omitted from the analyses of average selectivity values.

Species and stage specific consumption and production rates

Daily consumption rates by herring and sprat populations were determined for each cruise, based on i) the average amount of fish eggs by taxa and development stage in the diet of herring and sprat, ii) daily ration estimates from gastric evacuation modelling taking into account hydrographic conditions and iii) predator population sizes in the spawning area within the Bornholm Basin (areas enclosed by the $60 \mathrm{~m}$ depths isobath) estimated from population model outputs and hydroacoustic measurements. The estimation procedures are described in Neumann et al. (2017), here deployed for both cod and sprat egg consumption and on stage specific basis.

The egg production was determined for cod eggs as described by Neumann et al. (2017), but additionally considering each egg stage separately. This implied applying temperature dependent stage durations and stage specific egg mortality rates, the latter averaged for each sampling date weighted by the stage durations and finally averaged over all sampling dates. A similar procedure was applied to obtain estimates of sprat egg production.

The cumulative mortality in a stage and the potential impact of predation are dependent on stage duration. To account for different stage durations (Wieland et al. 1994), daily egg production rates were compared to daily consumption rates on an egg stage level. This comparison was confined to those fish egg taxa for which all parameters to calculate daily production rates (egg stage duration time in relation to ambient temperature) were available, i.e. cod and sprat.

\section{Results}

Fish eggs in the prey field 
In the Bornholm Basin, eggs of cod and sprat (Fig.1) as well as rockling and to a lesser extent dab and flounder (Table 2) were available as prey for herring and sprat. In spring, sprat eggs were dominant, i.e. on average around $80 \%$ of the total egg abundance, followed by cod $(\sim 15 \%)$, rockling $(>2 \%)$ and flounder $(<1 \%)$, and very few dab eggs. In summer, cod eggs (>85\% in abundance) were the main ichthyoplankton prey species available, followed by sprat $(\sim 5 \%)$, rockling ( 8 \%) and dab $(<1 \%)$ eggs, while founder eggs were absent. Mean abundance of cod eggs were similar in spring and summer except for stage la, which was more abundant in summer (Fig. 1). Abundance of cod eggs at stage IV was comparatively low, which is explained by hatching taking place at this stage. Rockling egg abundances were highly variable, with a maximum in summer 2005, reaching similar abundances as cod eggs, while no eggs were found in spring 2007 (Table 2).

The vertical distribution of fish eggs is species specific, however, over $90 \%$ of all eggs were distributed in and around the halocline, i.e. the water layer where also the stomach sampling was conducted. Cod eggs were distributed between $\sim 45 \mathrm{~m}$ and $85 \mathrm{~m}$ water depths with a maximum abundance around $60 \mathrm{~m}$ in both seasons. Sprat eggs dwell shallower, between the surface and $\sim 65 \mathrm{~m}$ depth with highest abundance around 50-55 $\mathrm{m}$ in spring and slightly shallower in summer (Fig. 2). Rockling eggs were distributed widely in the water column, with most eggs found around 50-60 m depth. Flounder and dab eggs occurred mostly in 60-70 m depth, with some dab eggs found down to $80 \mathrm{~m}$ depth.

\section{Fish eggs in the diet}

\section{Selectivity of fish eggs}

Comparing abundances of fish eggs in the diet and in the prey field showed that in spring, herring selected cod and in some cases rockling eggs and generally avoided sprat eggs (Fig. 3). Sprat ingested only a limited amount of fish eggs in 2005 and 2008, with none being identifiable to species level, and in the remaining years selected cod eggs. In summer, herring and sprat fed non-selectively on fish eggs of any species, besides herring avoiding rockling eggs in summer 2004 and 2005. Flounder and dab eggs were rarely identified in the diet, even when present in the prey field. To address the sensitivity of these results to the selection of stations and the averaging procedure adopted, station- 
specific selectivity indices (Table S1) were included in Fig. 3 indicating the lowest and highest indices for a given cruise. From the lack of overlapping ranges, it can be concluded, that the main results in terms of positive selection of cod eggs and avoidance of sprat eggs in spring were robust to the in some cases relatively large variability in station-specific indices.

Both herring and sprat positively selected cod eggs at stage III, with the exception of sprat in summer (Fig. 4). Egg stages IV and partly II were positively selected as well, while younger cod egg stages were fed upon non-selectively by both predators or even avoided (Fig. 4). Sprat eggs at earlier development stages were mainly avoided by both sprat and herring, while none-selective feeding or sometimes positive selection occurred on egg stage III. Rockling eggs at stage III were also more selected compared to younger stages, which often were found in the field, but not at all in the stomachs (Table S2).

\section{Daily ration of fish eggs}

Daily rations of cod eggs consumed by herring showed highest values for egg stage III in all investigated periods. Daily ration of young cod egg stages (la-II) were in general higher in summer than in spring, while the opposite was found for older egg stages (III-IV), with the exception of 2008 (Fig. 5). Daily rations of sprat eggs were generally low, while those few eggs consumed by herring in spring 2007 and 2008 were mainly stage III, similar to cod eggs. For sprat as predator, the daily rations of cod eggs were generally highest for stage II and III, both in spring and summer, with the exception of summer 2004 with the highest daily rations of egg stage la.

\section{Fish egg consumption vs. production}

The daily cod egg production increased from spring 2004 to 2008, being somewhat higher in summer than in spring. In spring, egg production was generally higher for sprat compared to cod (except in 2008). In summer, egg production by sprat was very low corresponding to the end of the spawning activity (Table 3). Opposite to cod egg production, predator abundances in spring showed a declining trend from 2004 to 2008. Highest total cod egg consumptions by herring was determined for summer 2007 ( 63

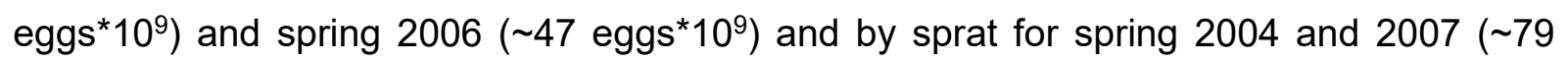
eggs* $\left.10^{9}\right)$. The consumption of sprat eggs was lower compared to cod, despite the high 
egg production in spring (Table 3). This is in line with the results from the prey selectivity investigation, suggesting that cod eggs are generally positively and sprat eggs negatively selected by both clupeid predators.

Comparison of stage specific cod egg daily production and consumption rates revealed a limited predation pressure on youngest cod egg stages by both predator species in both seasons. In contrast, in three spring situations (2004, 2006 and 2007), consumption of cod eggs at stage III exceeded production rates, which is also the case for egg stage II in 2004 (Table 3). This indicates high predation mortality on these older egg stages in these years, while in spring 2008 the overall predation pressure was low and in 2005 moderate (with $<50 \%$ of egg stage III production being consumed). Predation pressure on the oldest eggs stage IV is estimated to be lower than on egg stage III. However, as cod eggs in the Baltic hatch at stage IV, with development time depending on oxygen concentration at incubation (Wieland et al 1994), the estimates of daily production rates for stage IV are more uncertain. In summer, the predation pressure on cod eggs was generally lower; only in 2007 the estimates of daily consumption rate of cod eggs at stage III exceeded slightly the level of production, and in 2004 the consumption was estimated to be $\sim 50 \%$ of the production (Table 3 ).

For sprat eggs, comparing consumption to production rates revealed a considerably lower predation pressure than on cod eggs in spring, with highest predation pressure in 2006 and 2007 , corresponding to $5 \%$ of the production of eggs at stage III being consumed, followed by $4 \%$ and $1 \%$ in 2004 and 2005 (Table 3). The production of egg stage IV was very low in spring 2007, but similar to cod, the egg production estimates in this stage at which hatching occurs are uncertain. In summer 2004 and 2005, the consumed proportion of the stage III egg production was relatively high, i.e. $<16 \%$, but the production level at that time is only $5 \%$ of that in the main spawning season in spring, rendering this predation impact on overall egg survival to be limited.

\section{Discussion}

\section{Ichthyoplankton in clupeid diet}

Both herring and sprat mainly preyed upon cod and sprat eggs, and to a lesser degree on rockling eggs, while flounder and dab eggs were present in the diet only in small numbers confirming earlier results (Köster and Schnack 1994; Köster and Möllmann 2000a). In 
contrast to cod eggs, low numbers of cod larvae and fish larvae in general were detected in herring and sprat diets. This corroborates earlier findings, which explained this by a limited vertical overlap between the preferred medium-sized to larger larvae inhabiting the upper water layers above the halocline and the clupeids concentrating in deeper layers during the daily feeding period (Köster and Schnack 1994). Along these overall patterns, a high variability in both composition and quantity of ichthyoplankton in sprat and herring diet is evident (Neumann et al. 2014), both within a cruise as well as between seasons and years.

\section{Species selectivity}

Cod eggs were generally positively and sprat eggs negatively selected/ avoided in spring, which could partly be related to the vertical overlap of predator and prey (Neumann et al. 2014) rather than direct prey selectivity from a common prey field. In our data, the catching depth of the clupeids matches to a large extent the vertical distribution of cod and sprat eggs (Fig. 6). However, ideally, one would also need to consider at which depth the clupeids had actually been feeding prior capturing, which is unfortunately not possible with present technology. Sprat eggs are usually distributed in the upper part of the halocline (Fig. 6). Cod eggs float in the central and lower part and below the halocline with environmental conditions allowing successful egg development, i.e. a salinity of $>11 \mathrm{psu}$ and an oxygen concentration of >2 $\mathrm{ml} \mathrm{l}^{-1}$ (Nissling 1994; Wieland et al. 1994; Westin et al. 1991). Feeding of clupeids during day time takes place in the same water layer (Hinrichs 1986; Köster and Schnack 1994; Stepputtis et al. 2011), apart from a fraction of clupeids staying in uppermost water layers also during daytime (Fig. 6).

A consistent positive selectivity of cod eggs and an avoidance of sprat eggs during spring cruises imply that the hypothesis that the total abundance of fish eggs triggers selectivity of cod eggs, suggested by Köster and Möllmann (2000a) is not confirmed in this study. If predation on sprat eggs, which are far more abundant than cod eggs, would trigger clupeids also to forage on cod eggs, opposite selectivity indices for the two prey species would not be expected. This expectation is independent of whether the difference in selectivity is real or caused by different overlap of predator and prey.

The apparent positive selectivity of cod compared to sprat eggs could in principal also be related to a size difference, i.e. cod eggs being larger than sprat eggs (e. g. Nissling et al. 
2003). Earlier studies on cod and plaice eggs in the North Sea showed, that egg size was correlated with predation mortality (Rijnsdorp and Jaworski 1990). Herring are visual feeders, at least in situations with sufficient light conditions (e. g. Batty et al. 1990; Thetmeyer and Kils 1995), selecting for larger items (Dalpadado et al. 2000) with greater energy content (Leggett and DeBlois 1994) due to their better visibility (Wieland and Köster 1996; Zaret and Kerfoot 1975).

In summer, cod eggs were non-selectively consumed, while sprat eggs, in contrast to spring, were not avoided and in some cases even positively selected (Table S1). This can be explained by the majority of clupeids being distributed above the cod egg layer dwelling in water depths were sprat eggs are more abundant (Fig. 6). This supports earlier findings that depth, in addition to turbidity and time of day, influence prey detection (Baily and Houde 1989). Rockling eggs were occasionally positively selected by both predators, which may be related to the oil droplet in the rockling eggs enhancing their visibility compared to eggs of other species.

Some occasions were encountered when prey was present in the diet but not in the field or vice versa, which could represent a strong selectivity or avoidance, respectively. These occasions, possibly also related to sampling issues, were only indicated by "+" or "-"(Table S1, S2) instead of a quantitative index value. When fish eggs were found in the diet, but not in the field, the predator may have been feeding in a nearby - albeit not sampled - area with higher egg abundances before they were caught in the proximity of the reference ichthyoplankton station. The small-scale vertical predator prey overlap is neither considered in the selectivity index, due to uncertainties in the exact depth distribution of clupeids feeding prior to catching. Here our assumption is that clupeids are able to optimise their vertical position within and around the halocline, the water layer in which $>90 \%$ of the fish eggs are distributed. Horizontal small-scale variability in egg abundance can as well cause a mis-match between predator and prey, however, there is no indication from the standard ichthyoplankton surveys that such variability is high, i.e. there are hardly extreme outliers encountered (Neumann et al. 2014).

The determined average selectivity indices and conclusions on selectivity of different egg taxa appear to be robust to the deployed data averaging procedure, as the selectivity patterns from the indices by individual stations were mostly consistent with cruise-specific average selectivity, despite the in some cases considerable variability between stations 
(Fig. 3, Table S1).

\section{Selectivity of egg development stages}

Apart from size, better visibility may also be related to strong pigmentation that occurs within advanced egg development stages. In fact, Wieland and Köster (1996) demonstrated that cod egg selectivity by herring was related to better visibility of advanced egg stages rather than cod egg size. This is supported in the present study, as smaller sprat and rockling eggs in advanced development stage were in some cases selected similarly or even more than larger cod eggs at early development stages.

Both predators preferred advanced egg stages of cod, especially development stage III, but also stage IV and in certain occasions stage II. The relatively higher selectivity of egg stage III compared to younger stages is also apparent for sprat and rockling eggs. Eggs change their buoyancy during development (Wieland et al. 2000), resulting in a slightly deeper distribution of more developed eggs stages, but well within the range of vertical movement of both sprat and herring during their daily feeding period.

Depending on prey availability and density, herring can switch between different feeding modes: biting at low prey concentrations; biting, gulping and filtering at intermediate prey concentrations, and mainly filtering at high prey concentrations (Gibson and Ezzi 1990). Sprat, in contrast, is known as a strict selective/ particulate feeder that usually do not filterfeed (Bernreuther 2008; Möllmann et al. 2004), apart from at low light intensities (Bernreuther et al. 2013) or high turbidity (Falkenhaug and Dalpadado 2014). Visibility is the best explanation for preferring later stages of egg development for both sprat and herring, which is consistent with previous studies conducted in the Baltic Sea (Bernreuther et al. 2013; Wieland and Köster 1996) as well as in the North Sea (Thompson and Riley 1981; Segers et al. 2007) and the Irish Sea (Ellis and Nash 1997).

\section{Impact of predation on egg survival}

The predation pressure on cod eggs was found to be considerably higher than on sprat eggs. This can be explained by a pronounced vertical overlap between cod eggs and both clupeid predators in spring. The vertical overlap between predator and prey is defined by hydrographic conditions, with higher impact during stagnation period when insufficient oxygen concentrations prevent clupeids to dwell in bottom water layers, i.e. below the 
water depths of highest cod egg concentrations (Köster and Möllmann 2000a; Köster et al. 2005).

A pronounced difference in the vertical distribution of sprat and herring is not obvious in spring, as both clupeid species avoid the cold intermediate winter water layers, either staying in shallow water layers (above $30 \mathrm{~m}$ ) or in and below the halocline (below $50 \mathrm{~m}$ ) (Fig. 6), with the maximum depth depending on the oxygen concentration in the bottom water (Orlowski 1999; Stepputtis et al. 2011). In summer, herring tend to stay higher up in the water column than cod eggs (Fig. 6) exerting a more variable, moderate to high predation impact. Sprat is even shallower distributed than herring, where its main prey species, i.e. cladocerans are found (Neumann et al. 2014) explaining the low consumption of fish eggs in general and cod eggs in particular. Sprat as a predator is generally of less importance in summer due to lower abundance in the area, having largely left the basin after spawning.

In some occasions the total consumption of cod eggs exceeded egg production rates in our estimates, e.g. in spring 2004. This discrepancy has also been reported in earlier studies (Köster and Möllmann 2000a), and is in fact substantially reduced by Neumann et al. (2017) and in the present study. However, some mismatch still being present in some occasions indicates either an overestimation of the egg consumption or an underestimation of the egg production.

A direct measure of uncertainty of these estimates is extremely difficult to obtain, due to complex calculation procedures involving various steps of data rising and combination of different types of data and model applications. Thus, sensitivity analyses are considered the most feasible approach for evaluating the impact of uncertainties involved in the estimation procedures. These have partly been conducted and discussed by Neumann et al. (2017) suggesting that the main conclusions from the previous and the present study in terms of the relatively high predation on cod eggs compared to sprat eggs, with the highest predation impact on older egg stages, are robust against the uncertainties considered. A dedicated sensitivity study would be required to quantify the impact of various uncertainties associated with input data and individual steps in the complex estimation procedures. This would be useful for defining future focus areas for this type of research, where possible refinements would be most beneficial in terms of improving the precision of 
predation estimates. However, quantifying potential uncertainties would by itself not improve the estimates of most likely levels of predation pressure possible to obtain presently, which are in this paper based on state of the art monitoring data and scientific knowledge and models available guiding the methodological choices and assumptions at different calculation steps.

Our results clearly demonstrate that predation impact on sprat eggs is much lower than on cod eggs, also during main spawning season in spring, confirming earlier results from the 1990's (Köster and Möllmann 2000b). However, the relative contribution of predation to total sprat egg mortality is variable and may be at times high (Voss et al. 2012). Furthermore, the shorter spawning season of sprat in spring-early summer implies that all spawned eggs are exposed to a relatively higher egg predation in spring compared to summer, which is not the case for cod. On the other hand, cod egg development time (3 weeks on average at $4{ }^{\circ} \mathrm{C}$, Wieland et al. 1994 or 12 days at $9{ }^{\circ} \mathrm{C}$, Nissling 2004) is longer than for sprat $\left(\sim 7\right.$ days at $9{ }^{\circ} \mathrm{C}$, e. g. Nissling 2004), resulting in a longer time of exposure to predation. The Bornholm Basin is only one of the main spawning areas of sprat in the central Baltic, while egg predation in more eastern spawning areas of the Gdansk Deep and Gotland Basin is even less pronounced than in the Bornholm Basin (Geldmacher 1999). This difference between basins has been explained by a combination of deviating prey availability and light intensity in the dwelling depth of clupeids during their daily feeding period reducing the ability to actively select fish eggs (Köster and Möllmann 2000b).

A certain predatory impact by clupeids on rockling egg survival can also not be ruled out, due to a similar vertical distribution with cod eggs and a similar overall egg development time, i.e. from spawning to hatching (Battle 1930). As temperature related stage specific egg development rates are not available for this species, egg production estimates cannot be calculated and the impact of the predation not determined.

The stage specific predation on older cod egg development stages implies a higher impact of predation on cod recruitment than formerly thought, as those eggs at later development stages have already survived two critical phases. The first phase is the fertilisation of eggs, which depends on salinity concentrations (Plikshs et al. 1993). Next, egg survival depends on ambient oxygen levels. In an experimental study on daily egg mortality rates as a function of temperature $\left(2\right.$ to $7^{\circ} \mathrm{C}$ ) and oxygen concentration $\left(2\right.$ to $\left.8 \mathrm{ml} \mathrm{O}_{2} \mathrm{I}^{-1}\right)$, which 
resembles conditions in the central Baltic spawning area of cod, two phases of increased mortality were found (Wieland et al. 1994); first, during gastrulation (at stage Ib) and before closure of the blastoporus (transition to stage II), and second, prior to and potentially initiating hatching at stage IV. Thus eggs at stage II and III have a higher chance of survival than younger egg stages. Consequently a pronounced predation by sprat and herring on this egg stage may have a strong impact on egg survival and ultimately on cod recruitment.

A key message from the present study is that not only specific life stages, but also specific development stages within a life stage may be much more vulnerable to predation than others. Investigating prey selectivity by pelagic fish to delineate prey preferences has proven more difficult than expected, as predators obviously utilise variability in small scale spatial distribution of the prey to optimise food intake, a process described by Frank and Leggett (1984) for demersal predators, but difficult to resolve with standard sampling techniques for pelagic fish. Furthermore, variation in feeding behaviour, e.g. switching between raptorial and filter feeding depending on prey type, behaviour and density as well as visibility and hydrographic conditions (Bailey and Houde 1989), render field based investigations of prey selectivity and preferences of pelagic fish difficult. This suggests that direct observations or experimental studies are needed to determine prey preferences of pelagic fish.

\section{Acknowledgements}

This study is part of the Joint Baltic Sea research and development programme (BONUS, Art 185) projects, integrating spatial processes into ecosystem models for sustainable utilisation of fish resources (INSPIRE) and Biodiversity changes-causes, consequences and management implications (BIO-C3); funded by the European Union's Seventh Framework Programme for Research, Technological Development and Demonstration and Innovation Fund Denmark. The authors are grateful to the RV Alkor crew and supporting scientific staff. We would also like to thank Matthias Schaber, Christoph Petereit and anonymous reviewers of earlier versions of this paper whose comments were valuable contributions to this work.

\section{References}


Bailey, K.M. and Houde, E.D. 1989. Predation on eggs and larvae of marine fishes and the recruitment problem. Adv. Mar. Biol. 25:1-83.

Battle, H.J. 1930. Spawning periodicity and embryonic death rate of Enchelyopus cimbrius (L.) in Passamaquoddy bay. Contrib. Can. Biol. Fish. 5: 361-380.

Batty, R.S., Blaxter, J.H.S., and Richard, J.M. 1990. Light intensity and the feeding of herring, Clupea harengus. Mar. Biol. 107: 383-388.

Berg, J. 1979. Discussion of Methods of Investigating the Food of Fishes, with Reference to a Preliminary Study of the Prey of Gobiusculus flavescens (Gobiidae). Mar. Biol. 50: 263-273. doi:10.1007/BF00394208

Bernreuther, M., Herrmann, J.-P., and Temming A. 2008. Laboratory experiments on the gastric evacuation of juvenile herring (Clupea harengus L.). J. Exp. Mar. Biol. Ecol. 363: 1-11. doi.org/10.1016/j.jembe.2008.05.012

Bernreuther, M., Schmidt, J., Stepputtis, D., and Temming, A. 2013. Vertically resolved prey selectivity and competition of Baltic herring Clupea harengus and sprat Sprattus sprattus. Mar. Ecol. Prog. Ser. 489: 177-195. doi:10.3354/meps10405

Brownell, C.L. 1985. Laboratory analysis of cannibalism by larvae of the cape anchovy Engraulis capensis. Trans. Am. Fish. Soc. 114: 512-518.

Cardinale, M., and Arrhenius, F. 2000. The influence of stock structure and environmental conditions on the recruitment process of Baltic cod estimated using a generalized additive model. Can. J. Fish. Aquat. Sci. 57: 2402-2409. doi: 10.1139/f00-221

Carstensen, J., Andersen, J., Gustafsson, B.B., Conley, D.J. 2014. Deoxygenation of the Baltic Sea during the last century. PNAS 111(15): 5628-5633.

Casini, M., Cardinale, M., and Arrhenius, F. 2004. Feeding preferences of herring (Clupea harengus) and sprat (Sprattus sprattus) in the southern Baltic Sea. ICES J. Mar. Sci. 61: 1267-1277. doi:10.1016/j.icesjms.2003.12.011

Dalpadado, P., Ellertsen, B., Melle, W., and Dommasnes, A. 2000. Food and feeding conditions of Norwegian spring-spawning herring (Clupea harengus) through its feeding migrations. ICES J. Mar. Sci. 57: 843-857.

Ellis, T., and Nash, R.D.M. 1997. Predation by sprat and herring on pelagic fish eggs in a plaice spawning area in the Irish Sea. J. Fish Biol. 50: 1195-1202. 
doi:10.1111/j.1095-8649.1997.tb01647.x

Falkenhaug T., and Dalpadado, P. 2014. Diet composition and food selectivity of sprat (Sprattus sprattus) in Hardangerfjord, Norway, Mar. Biol. Res. 3: 203215. doi:10.1080/17451000.2013.810752

Flinkman, J., Vuorinen, I., and Aro, E. 1992. Planktivorous Baltic herring (Clupea harengus) prey selectively on reproducing copepods and cladocerans. Can. J. Fish. Aquat. Sci. 49: 73-77. 10.1139/f92-008

Flinkman, J., Aro, E., Vuorinen, I., and Viitasalo, M. 1998. Changes in northern Baltic zooplankton and herring nutrition from 1980s to 1990s: Top-down and bottom-up processes at work. Mar. Ecol. Prog. Ser. 165: 127-136.

Frank, K.L., and Leggett, W.C. 1984. Selective exploitation of capelin (Mallotus vilosus) eggs by winter flounder (Pseudopleuronectes americanus): caplin egg mortality rates, and contribution of egg energy to the annual growth of flounder. Can. J. Fish. Aquat. Sci. 41: 1294-1302. 10.1139/f84-158

Geldmacher, A., and Wieland, K. 1999. Implications of mechanical deformation and formaldehyde preservation for the identification of stage-specific characteristics of Baltic cod eggs. J. Appl. Ichthyol. 15: 75-79.

doi: 10.1046/j.1439-0426.1999.00093.x

Gibson, R.N., and Ezzi, I.A. 1990. Relative importance of prey size and concentration in determining the feeding behaviour of the herring Clupea harengus. Mar. Biol. 107: 357-362.

Heath M.R. 1992. Field investigations of the early life stages of marine fish, Adv. Mar. Biol. 28: 1-174. doi.org/10.1016/S0065-2881(08)60039-5

Hinrichs, R. 1986. Nahrungsuntersuchungen und diurnaler Rhythmus der Nahrungsaufnahme von Hering und Sprott der Ostsee. Fisch. Forschung, 24: 31-37.

Hunter, J.R. 1982. Predation and recruitment. Fish Ecology III, University of Miami Technical Report 82008, 172-209.

Hunter, J.R. 1984. Inferences regarding predation on the early life stages of cod and other fishes. In "The Propagation of Cod" (eds. E. Dahl, D. D. Danielssen, E. Moksness and P. Solemdal). Flødevigen Rapportseries 1: 533-562. 
Karaseva, E.M., Patokina, F.A., and Kalinina, N.A. 2013. Fish Eggs and Larvae in the Diet of Herring Clupea harengus membras Linnaeus, 1758 and the Sprat Sprattus sprattus balticus (Schneider, 1904) (Clupeidae) in the Southeastern Baltic Sea. Russ. J. Mar. Biol. 39: 350-356. doi:10.1134/S1063074013050040

Köster, F.W. 1994. Der Einfluss von Bruträubern auf die Sterblichkeit früher Jugendstadien des Dorsches (Gadus morhua) und der Sprotte (Sprattus sprattus) in der zentralen Ostsee. Berichte Institut für Meereskunde, Kiel 261: 286 pp.

Köster, F.W., and Möllmann, C. 2000a. Trophodynamic control by clupeid predators on recruitment success in Baltic cod? ICES J. Mar. Sci. 57: 310-323. doi:10.1006/jmsc.1999.0528.

Köster, F.W., and Möllmann, C. 2000b. Egg cannibalism in Baltic sprat Sprattus sprattus. Mar. Ecol. Prog. Ser. 196: 269-277. doi:10.3354/meps196269

Köster, F.W., and Schnack, D. 1994. The role of predation on early life stages of cod in the Baltic. Dana 10: 179-201.

Köster, F.W., Huwer. B., Hinrichsen, H.-H., Neumann, V., Makarchouk, A., Eero, M., V. Dewitz, B., Hüssy, K., Tomkiewicz, J., Margonski, P., Temming, A., Hermann, J.-P., Oesterwind, D., Dieking, J., Kotterbra, P., and Plikshs, M. 2017. Eastern Baltic cod recruitment revisited - dynamics and impacting factors. ICES J. Mar. Sci. 74: 3-19.

doi.org/10.1093/icesjms/fsw172

Köster, F.W., Möllmann, C., Hinrichsen, H.-H., Wieland, K., Tomkiewicz, J., Kraus, G., Voss, R., Markarchouk, A., MacKenzie, B.R., St.John, M.A., Schnack, D., Rohlf, N., Linkowski, T., and Beyer, J.E. 2005. Baltic cod recruitment the impact of climate variability on key processes. ICES J. Mar. Sci. 62:1408-1425. doi:10.1016/j.icesjms.2005.05.004

Leggett, W.C., and DeBlois, E. 1994. Recruitment in marine fishes: is it regulated by starvation and predation in the egg and larval stages? Neth. J. Sea Res. 32: 119-134. doi.org/10.1016/0077-7579(94)90036-1

Möllmann, C., Kornilovs, G., and Sidrevic, L. 2000. Long-term dynamics of main mesozooplankton species in the central Baltic Sea. J Plankton Res. 22: 2015-2038. doi.org/10.1093/plankt/22.11.2015 
Neumann, V., Köster, F.W., Schaber, M., and Eero M. 2014. Recovery in eastern Baltic cod: is increased recruitment caused by decreased predation on early life stages? ICES J. Mar. Sci. 71: 1382-1392.

doi.org/10.1093/icesjms/fsu112.

Neumann, V., Schaber, M., Eero, M., Böttcher, U., and Köster, F.W. 2017. Quantifying predation on Baltic cod early life stages. Can. J. Fish. Aquat. Sci. 74: 833-842. doi: 10.1139/cjfas-2016-0215

Nilsson, L. A. F., Thygesen, U. H., Lundgren, B., Nielsen, B. F., Nielsen, J. R., and Beyer, J. E. 2003. Vertical migration and dispersion of sprat (Sprattus sprattus) and herring (Clupea harengus) schools at dusk in the Baltic Sea. Aquat. Liv. Res.16: 317-324.

Nissling, A. 1994. Survival of eggs and yolk sac larvae of Baltic cod (Gadus morhua) at low oxygen levels in different salinities. ICES Mar. Sci. Symp. 198: 626631.

Nissling, A. 2004. Effects of temperature on egg and larval survival of cod (Gadus morhua) and sprat (Sprattus sprattus) in the Baltic Sea - implications for stock development. Hydrobiologia 514: 115-123.

doi:10.1023/B:hydr.0000018212.88053.aa

Nissling, A., Müller, A., and Hinrichsen, H.-H. 2003. Specific gravity and vertical distribution of sprat eggs in the Baltic Sea. J. Fish Biol. 63: 280-299. doi:10.1046/j.1095-8649.2003.00139.

Orlowski, A. 1999. Acoustic studies of spatial gradients in the Baltic: implications for fish distribution. ICES J. of Mar. Sci. 56: 561-570. doi.org/10.1006/jmsc.1999.0484

Plikshs, M., Kalejs, M., and Grauman, G. 1993. The influence of environmental conditions and spawning stock size on the year-class strength of the eastern Baltic cod. ICES CM J: 22.

Prodanov, K., Mikhailov, K., Daskalov, G.M., Maxim, C., Chashchin, A., Arkhipov, A., Shlyakhov, V., and Ozdamar. E. 1997. Environmental management of fish resources in the Black Sea and their rational exploitation. GFCM Studies and Reviews 69: 178 pp. 
Rijnsdorf, A.D., and Jaworski, A. 1990. Size-selective mortality in plaice and cod eggs: a new method in the study of egg mortality. J. Cons. Int. Explor. Mer. 47: 256-263.

Rudstam L.G., Aneer, G., and Hildén, M. 1994. Top-down control in the pelagic Baltic ecosystem. Dana 10: 105-129.

Segers, F.H.I.D., Dickey-Collas, M., and Rijnsdorp, A.D. 2007. Prey selection by North Sea herring (Clupea harengus) with special reference to fish eggs. ICES J. Mar. Sci. 64: 60-68. doi:10.1093/icesjms/fsI002.

Sissenwine, M.P. 1984. Why do fish populations vary? In Exploitation of Marine Communities, pp. 59-94. Ed. by R. M. May. Springer Verlag, Berlin. 366 pp.

Stepputtis, D., Hinrichsen, H-H., Böttcher, U., Götze, E., and Morholz, V. 2011. An example of meso-scale hydrographic features in the central Baltic Sea and their influence on the distribution and vertical migration of sprat, Sprattus sprattus balticus (Schn.). Fish. Oceanogr. 20: 82-88. doi:10.1111/j.1365-2419.2010.00567.x.

Swain, D.P., and Sinclair, A.F. 2000. Pelagic Fishes and the Cod Recruitment Dilemma. Can. J. Fish. Aquat. Sci. 57: 1321-1325. doi:10.1139/f00-104.

Thetmeyer, H., and Kils, U. 1995: To see and not to be seen: the visibility of predator and prey with respect to feeding behaviour. Mar. Ecol. Prog. Ser. 126: 1-8.

Thompson, B.M., and Riley, J.D. 1981. Egg and larval development studies in the North Sea cod (Gadus morhua L). Rapp. p.-v. réun. - Cons. int. explor. mer. 178: 553-559.

Voss, R., Petereit, C., Schmidt, J.O., Lehmann, A., Makarchouk, A., and Hinrichsen, H.-H. 2012. The spatial dimension of climate-driven temperature change in the Baltic Sea and its implication for cod and sprat early life stage survival. J Mar. Sys. 100: 1-8. doi.org/10.1016/j.jmarsys.2012.03.009

Westin, L., and Nissling, A. 1991. Effects of salinity on spermatozoa motility, percentage of fertilized eggs and egg development of Baltic cod (Gadus morhua L.), and implications for cod stock fluctuations in the Baltic. Mar. Biol. 108: 59 . 
Wieland, K., and Köster, F.W. 1996. Size and visibility of Baltic cod eggs with reference to size-selective and stage-dependent predation mortality. J. Appl. Ichthyol. 12: 83-89. doi: 10.1111/j.1439-0426.1996.tb00067.x

Wieland, K., Waller, U., and Schnack, D. 1994. Development of Baltic cod at different levels of temperature and oxygen content. Dana 10: 163-177.

Wieland, K., Jarre-Teichmann, A., and Horbowa, K. 2000. Changes in the timing of spawning of Baltic cod: possible causes and implications for recruitment. ICES J Mar. Sci. 57: 452-464. doi:10.1006/jmsc.1999.0522

Zaret, T.M., and Kerfoot, W.C. 1975: Fish predation on Bosmina longirostris: Body-size vs. visibility selection. Ecology 56: 232-237. doi: 10.2307/1935317 


\section{Figures}

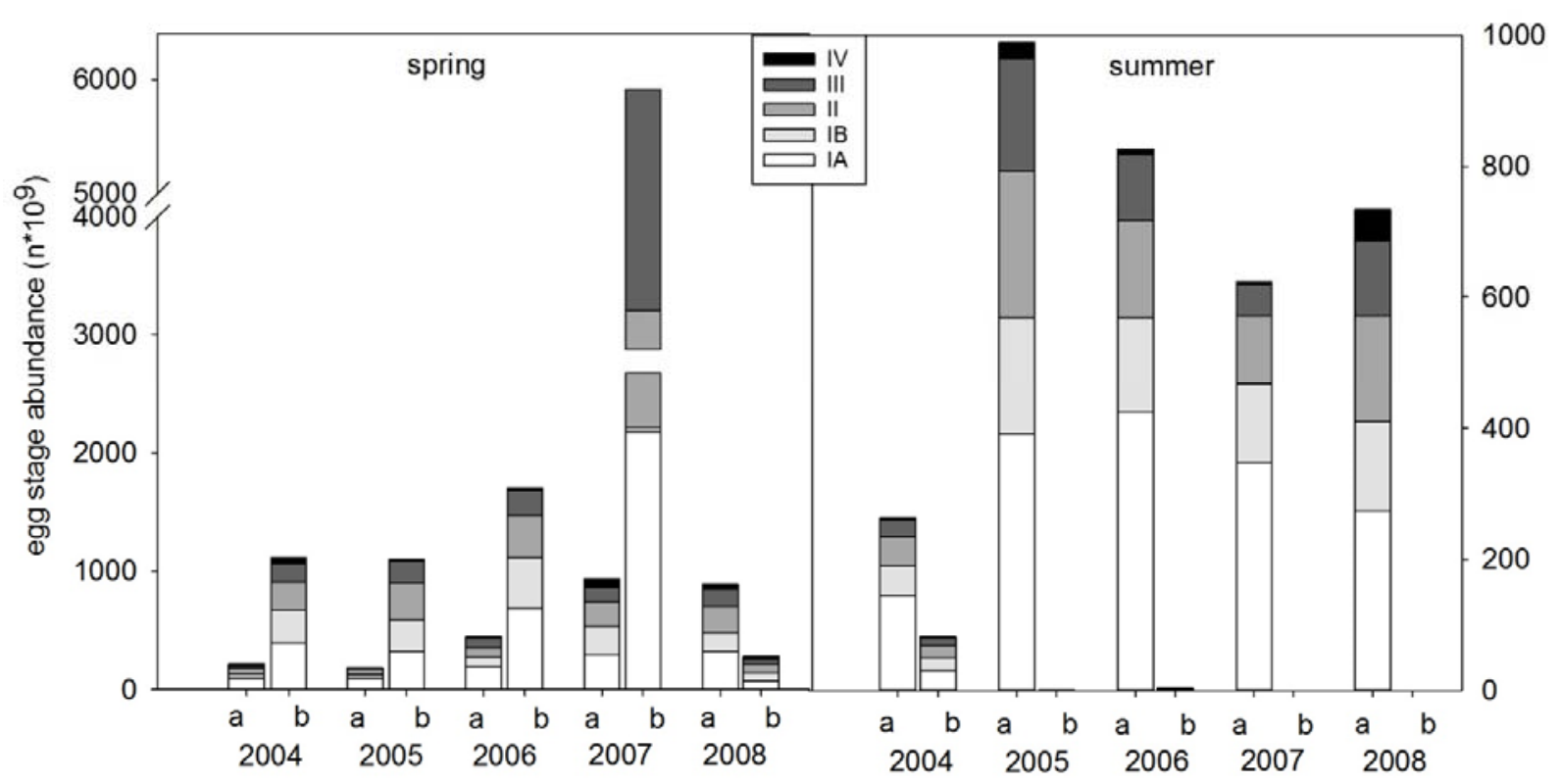

Figure 1: Egg abundance of $\operatorname{cod}(\mathrm{a})$ and sprat (b) at development stages I-IV in the Bornholm Basin with water depth of $>60 \mathrm{~m}$ in spring (left, scale max. $6000 \mathrm{n}^{*} 10^{9}$ ) and summer (right, scale max. $1000 \mathrm{n}^{*} 10^{9}$ ) 2004-2008. 

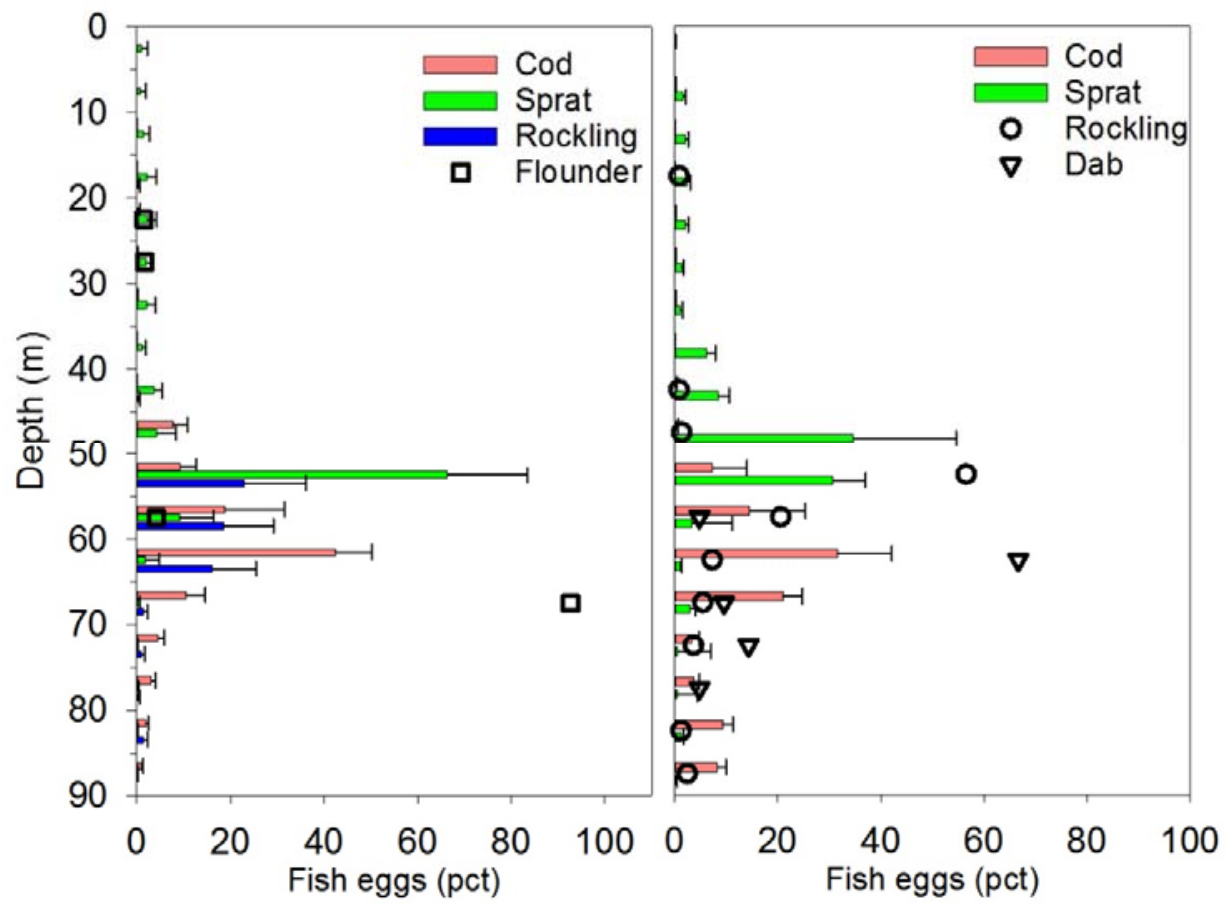

Figure 2: Vertical distribution of fish eggs in the Bornholm Basin as percentages (pct) of eggs at different depths, including standard errors, based on average distributions observed in 2004-2008. Standard errors are shown only where data from at least 3 samples were available. 


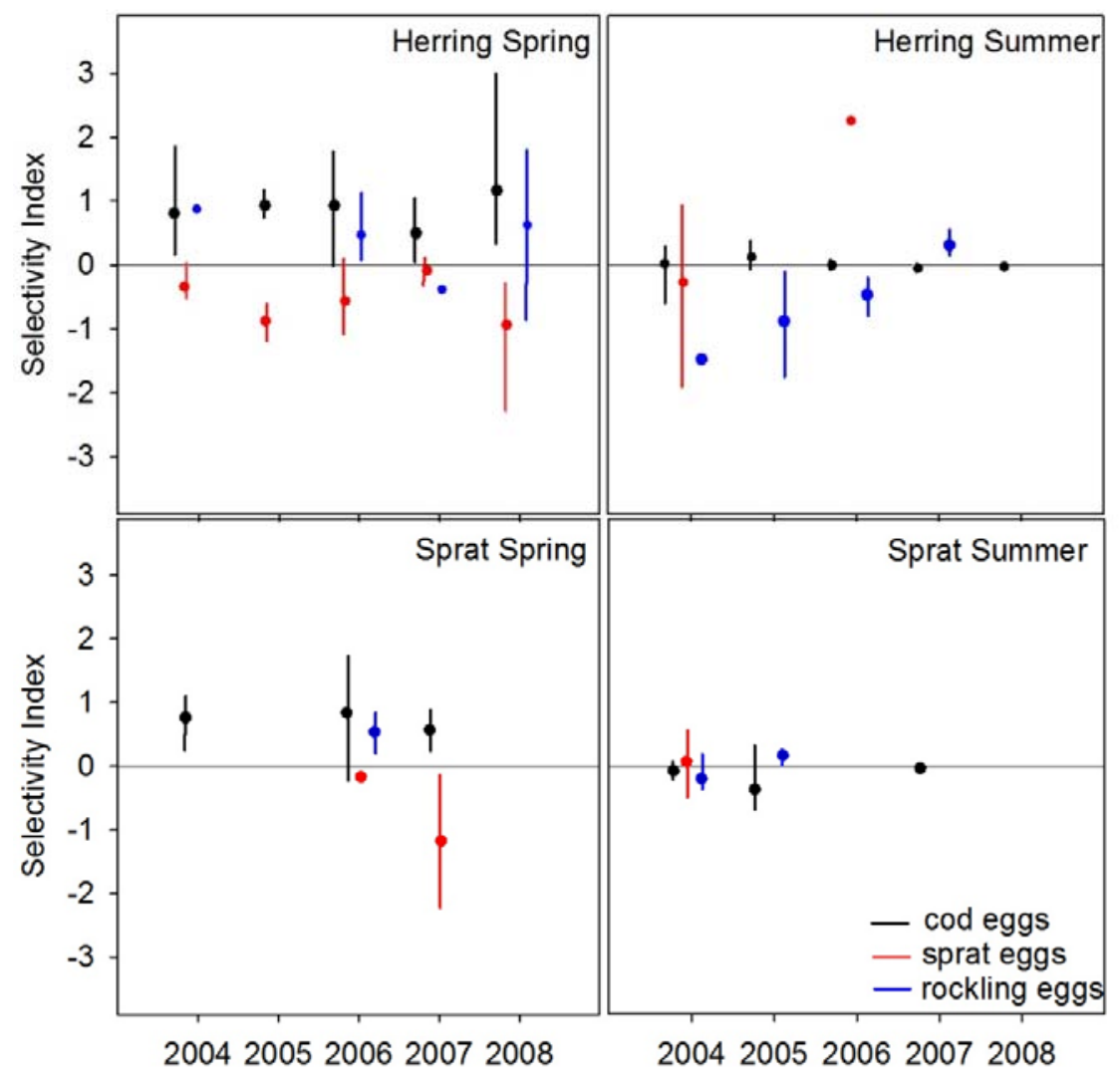

Figure 3: Shorigin Selectivity Indices for different fish egg taxa consumed by sprat and herring in spring and summer 2004-2008. The vertical lines represent the ranges (minimum and maximum) of the values determined for individual stations, with the mean (dots) indicating the average prey selectivity. 

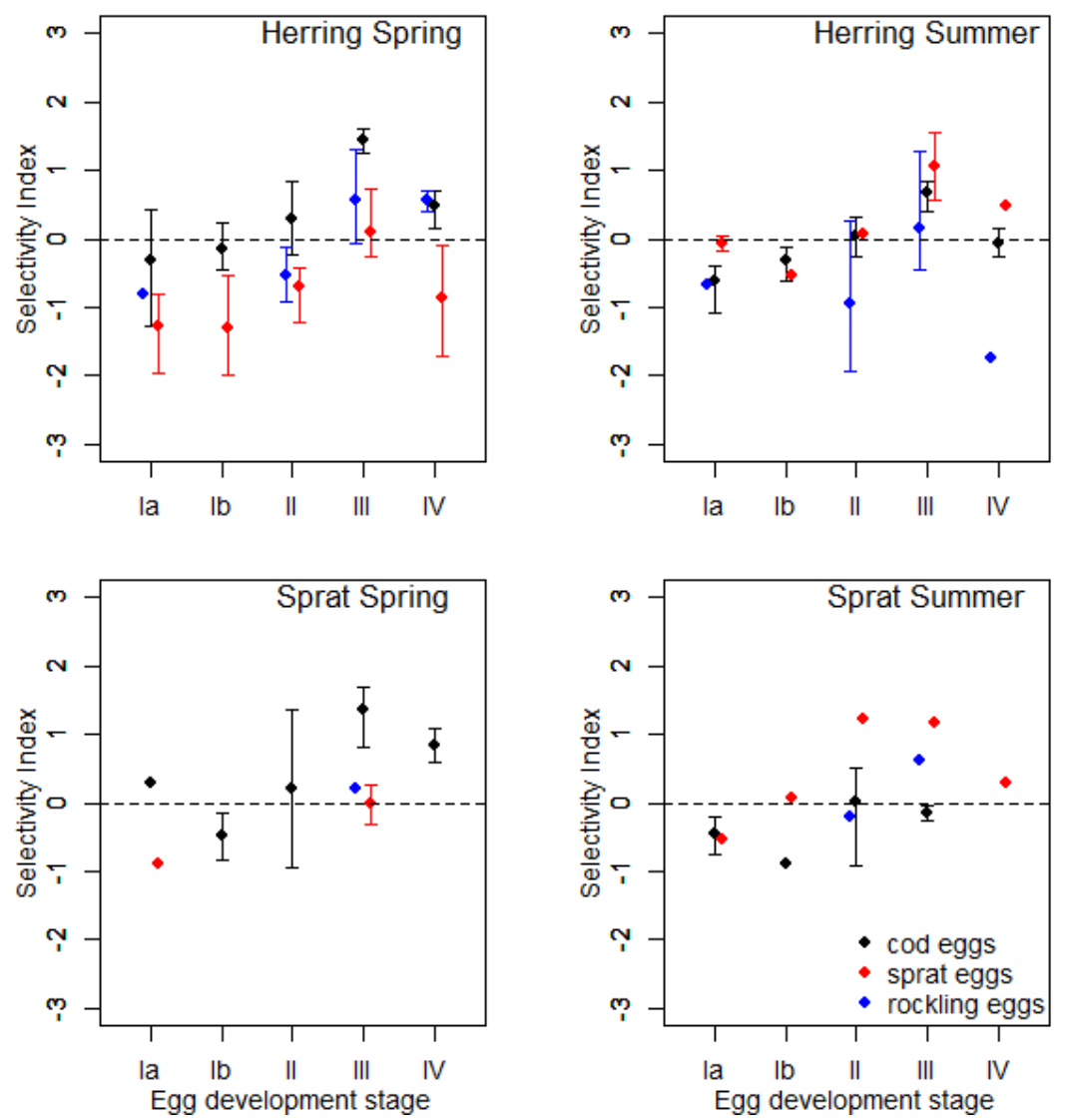

Figure 4. Shorigin Selectivity Indices for different development stages (la-IV) of eggs of different taxa consumed by sprat and herring in spring and summer. The vertical lines represent the ranges (minimum and maximum) of the values determined for individual cruises in different years, with the mean (dots) indicating the average prey selectivity. 

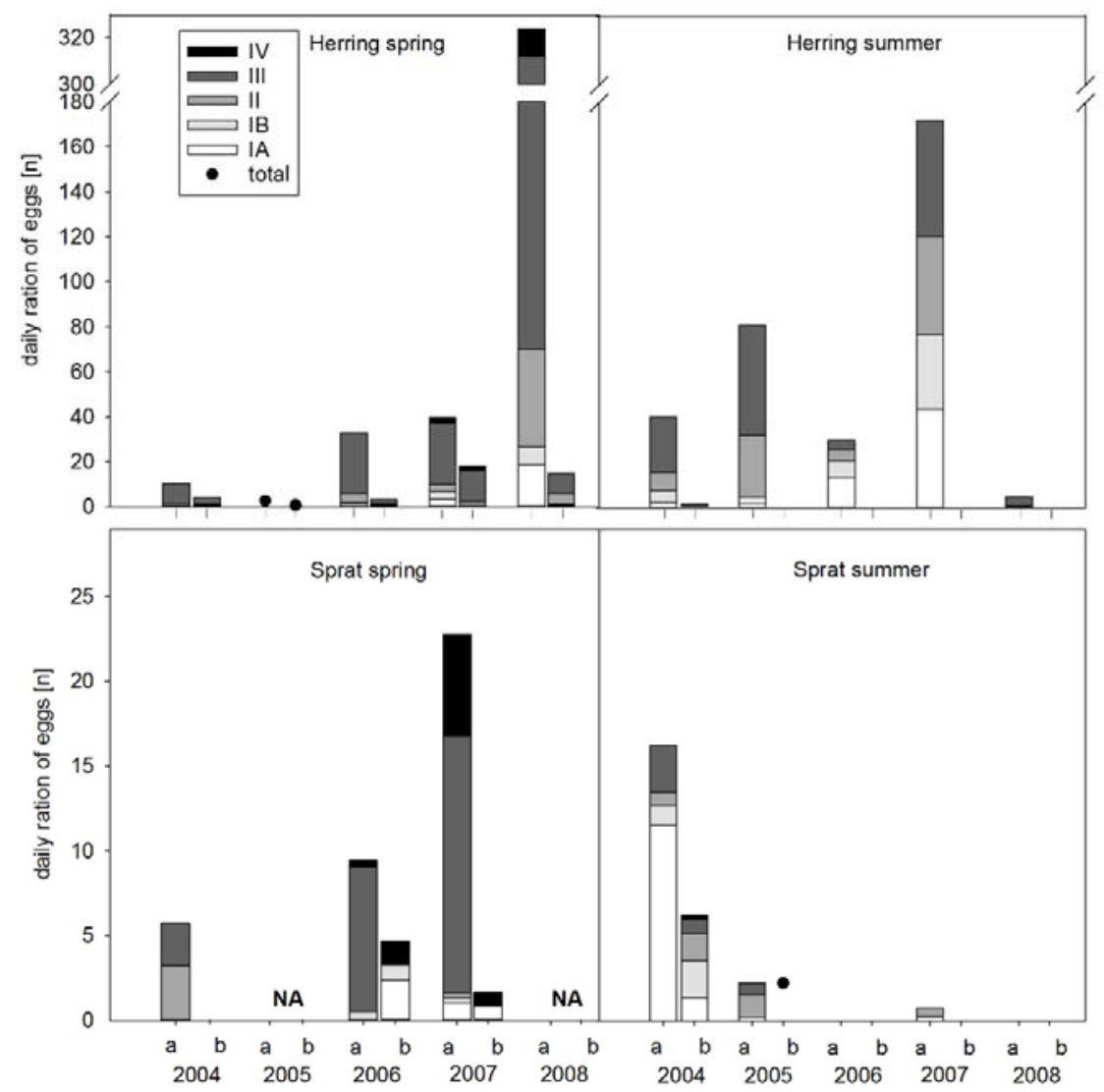

Figure 5: Daily rations at different egg stages (stacked bar) of cod (a) and sprat (b) by individual herring and sprat in spring and summer 2004-2008. NA: Eggs could not be identified to species; Black dots: Eggs could not be staged and indicate the total numbers of $\operatorname{cod}(a)$ or sprat eggs (b). 


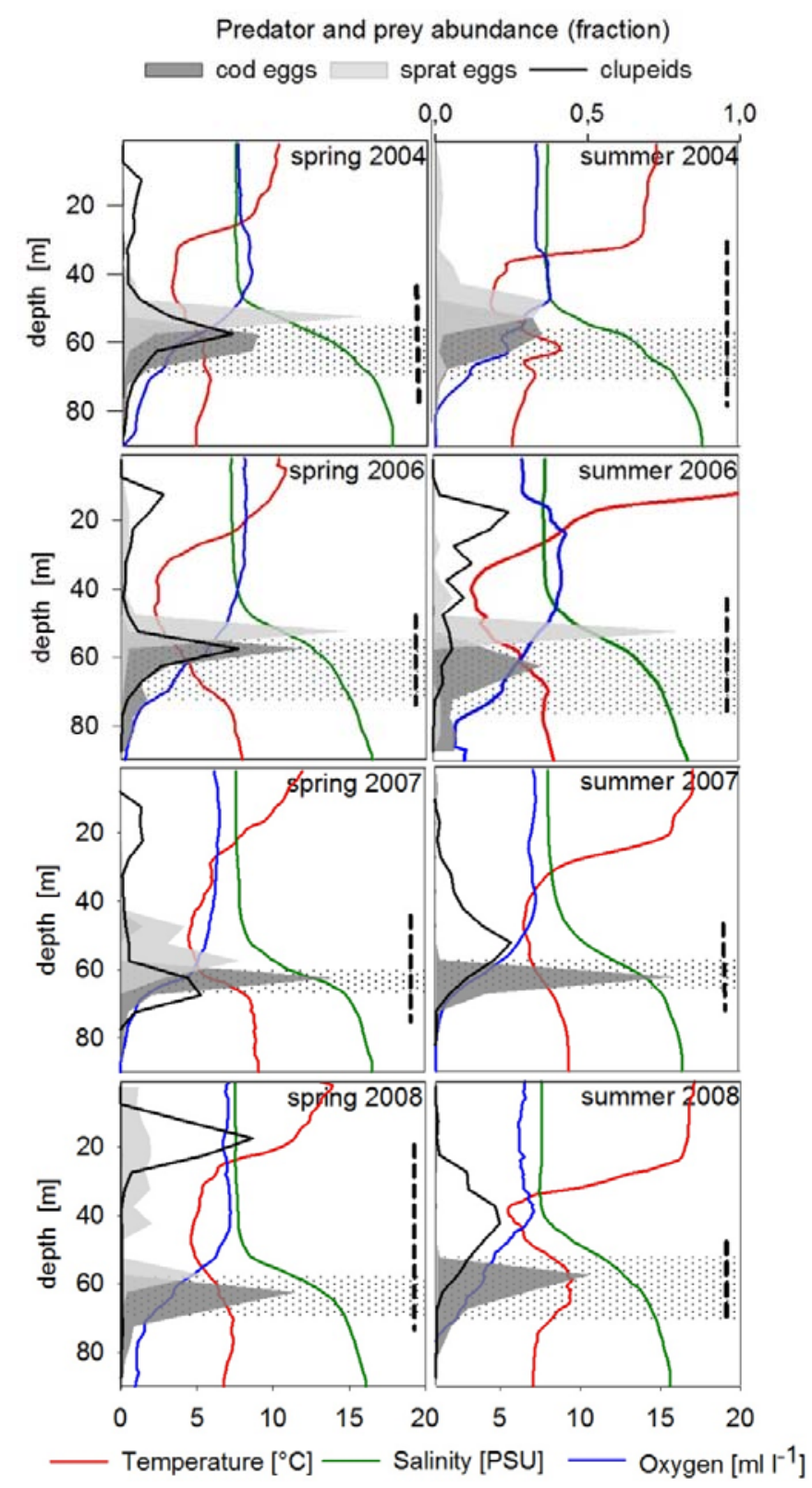

Figure 6: Relative vertical distribution of cod eggs (dark grey area) and sprat eggs (light grey area) as well as clupeid predators (black lines) and hydrographic conditions (coloured lines) in spring and summer 2004-2008. Dotted area: Reproductive volume of cod eggs ( $\geq$ $2 \mathrm{ml}$ oxygen and $\geq 11 \mathrm{psu}$ ). Vertical dashed line (black): Depth range of clupeid catches (with varying depth per station). No data available in 2005 and no vertical clupeid abundances in summer 2004. Sprat eggs were absent in summer 2007 and 2008. 


\section{Tables}

Table 1: Sampling dates in spring and summer 2004-2008, number of trawl (clupeid stomachs) and Bongo (fish eggs) stations in the Bornholm Basin ( $\geq 60 \mathrm{~m}$ water depth) of the Baltic Sea as well as total number of herring and sprat stomachs included for the analysis of egg consumption (total) and egg selectivity. *1 all eggs were unidentified; *2 no eggs ingested by predators but available in the field.

\begin{tabular}{|c|c|c|c|c|c|c|c|}
\hline \multirow{3}{*}{$\begin{array}{r}\text { Cruise data } \\
\text { Spring }\end{array}$} & & & & \multicolumn{4}{|c|}{ Number of stomachs } \\
\hline & & \multicolumn{2}{|c|}{ Number of stations } & \multicolumn{2}{|c|}{ Total } & \multicolumn{2}{|c|}{ Selection analysis } \\
\hline & & Trawl & Bongo & Herring & Sprat & Herring & Sprat \\
\hline & 2-4 June 2004 & 10 & 37 & 169 & 258 & 105 & 85 \\
\hline & 29-31 May 2005 & 10 & 36 & 287 & 234 & 64 & $* 1$ \\
\hline & 8-10 June 2006 & 10 & 35 & 262 & 265 & 232 & 189 \\
\hline & 28 May- 2 June 2007 & 12 & 37 & 168 & 314 & 151 & 87 \\
\hline & 7-9 June 2008 & 14 & 36 & 303 & 167 & 303 & $* 1$ \\
\hline \multicolumn{8}{|l|}{ Summer } \\
\hline & 19-21 July 2004 & 14 & 28 & 415 & 279 & 385 & 92 \\
\hline & 22-25 July 2005 & 13 & 36 & 386 & 211 & 232 & 86 \\
\hline & 27-30 July 2006 & 12 & 37 & 296 & 51 & 22 & $* 2$ \\
\hline & 2-5 August 2007 & 19 & 35 & 459 & 291 & 319 & 44 \\
\hline & 23-27 August 2008 & 12 & 35 & 315 & 65 & 225 & $* 2$ \\
\hline
\end{tabular}


Table 2: Egg abundance $\left(\mathrm{n}^{*} 10^{9}\right)$ of rockling, dab and flounder in spring and summer in the Bornholm Basin (water depth of $>60 \mathrm{~m}$ ).

\begin{tabular}{|c|c|c|c|c|c|c|}
\hline & spring & summer & spring & summer & spring & summer \\
\hline year & rockling & & dab & & flounder & \\
\hline 2004 & 29 & 22 & 0,1 & 1 & 0,11 & 0 \\
\hline 2005 & 41 & 408 & 2,4 & 0 & 0 & 0 \\
\hline 2006 & 101 & 44 & 2,1 & 0,2 & 0 & 0 \\
\hline 2007 & 0 & 14 & 0 & 0 & 0 & 0 \\
\hline 2008 & 45 & 9 & 1 & 0,2 & 0 & 0 \\
\hline
\end{tabular}


Table 3: Daily production and consumption of cod (upper part) and sprat eggs (lower part) by herring and sprat populations in spring and summer 2004-2008. NA: eggs could not be identified to stage level.

\begin{tabular}{|c|c|c|c|c|c|c|c|c|c|c|c|c|c|c|c|c|c|c|c|}
\hline \multicolumn{6}{|c|}{ daily production $\left(n * 10^{9}\right)$} & \multicolumn{2}{|c|}{ abundance } & \multicolumn{6}{|c|}{ consumption $\left(n^{*} 10^{9}\right)$ by herring } & \multicolumn{6}{|c|}{ consumption $\left(n^{*} 10^{9}\right)$ by sprat } \\
\hline \multicolumn{6}{|c|}{ cod eggs } & \multicolumn{2}{|c|}{ predator $\left(n * 10^{6}\right)$} & \multicolumn{12}{|c|}{ cod eggs } \\
\hline spring & IA & IB & ॥ & III & IV & herring & sprat & total & la & $\mathrm{lb}$ & II & III & IV & total & la & Ib & II & III & IV \\
\hline 2004 & 39 & 24 & 18 & 8 & 7 & 1205 & 13907 & 12,7 & 0,2 & 0,5 & 0,9 & 10,9 & 0,2 & 79,5 & 0 & 0 & 44,9 & 34,6 & 0 \\
\hline 2005 & 46 & 24 & 16 & 7 & 1 & 1335 & 14328 & 3,7 & NA & NA & NA & NA & NA & \multicolumn{6}{|c|}{ only unidentified eggs } \\
\hline 2006 & 97 & 55 & 41 & 27 & 6 & 1420 & 3357 & 46,9 & 2,1 & 0,5 & 6,3 & 37,7 & 0,4 & 31,8 & 0 & 1,6 & 0 & 28,6 & 1,6 \\
\hline 2007 & 163 & 175 & 104 & 47 & 44 & 768 & 3486 & 30,5 & 2,6 & 2,7 & 2,2 & 21 & 2 & 79,3 & 3,6 & 1,1 & 1 & 52,8 & 20,9 \\
\hline $\begin{array}{r}2008 \\
\text { summer }\end{array}$ & 202 & 124 & 119 & 56 & 24 & 40 & 214 & 12,9 & 0,8 & 0,3 & 1,7 & 9,7 & 0,5 & & \multicolumn{4}{|c|}{ only unidentified eggs } & \\
\hline 2004 & 74 & 31 & 21 & 9 & 2 & 135 & 480 & 5,5 & 0,3 & 0,7 & 1,1 & 3,3 & 0 & 7,8 & 5,5 & 0,6 & 0,4 & 1,3 & 0 \\
\hline 2005 & 227 & 129 & 113 & 60 & 15 & 55 & 315 & 4,5 & 0,1 & 0,2 & 1,5 & 2,7 & 0 & 0,7 & 0,1 & 0 & 0,4 & 0,2 & 0 \\
\hline 2006 & 293 & 118 & 85 & 40 & 4 & 139 & 91 & 4,2 & 1,9 & 1,1 & 0,7 & 0,5 & 0 & 0 & 0 & 0 & 0 & 0 & 0 \\
\hline 2007 & 221 & 93 & 56 & 18 & 2 & 364 & 539 & 62,6 & 15,9 & 12 & 15,9 & 18,7 & 0 & 0,4 & 0,1 & 0 & 0,3 & 0 & 0 \\
\hline 2008 & 227 & 129 & 104 & 51 & 37 & 130 & 381 & 0,6 & 0 & 0 & 0,1 & 0,5 & 0 & 0 & 0 & 0 & 0 & 0 & 0 \\
\hline \multicolumn{20}{|c|}{ sprat eggs } \\
\hline spring & & & & & & & & & & & & & & & & & & & \\
\hline 2004 & 282 & 546 & 465 & 129 & 37 & 1205 & 13907 & 7,8 & 1,1 & 0,4 & 0,8 & 5,5 & 0 & 0 & 0 & 0 & 0 & 0 & 0 \\
\hline 2005 & 231 & 505 & 604 & 152 & 12 & 1335 & 14328 & 1,2 & NA & NA & NA & NA & NA & \multicolumn{6}{|c|}{ only unidentified eggs } \\
\hline 2006 & 466 & 799 & 675 & 168 & 13 & 1420 & 3357 & 7,1 & 1 & 0,4 & 1,8 & 3,8 & 0,1 & 7,8 & 2,9 & 0 & 0 & 4,9 & 0 \\
\hline 2007 & 865 & 70 & 2208 & 405 & 0 & 768 & 3486 & 23,3 & 1,3 & 1,6 & 0,3 & 17,5 & 2,7 & 2,9 & 0 & 0 & 0 & 2,9 & 0 \\
\hline $\begin{array}{r}2008 \\
\text { summer }\end{array}$ & 58 & 162 & 175 & 60 & 17 & 40 & 214 & 1 & 0 & 0 & 0,3 & 0,6 & 0 & & only & unide & ntifie & eggs & \\
\hline 2004 & 17 & 33 & 30 & 12 & 2 & 135 & 480 & 2,3 & 0,2 & 0,1 & 0,3 & 1,5 & 0,2 & 3 & 0,7 & 1,1 & 0,8 & 0,4 & 0,1 \\
\hline 2005 & 0 & 0 & 1 & 0 & 0 & 55 & 315 & 0 & 0 & 0 & 0 & 0 & 0 & 0,1 & NA & NA & NA & NA & NA \\
\hline 2006 & 1 & 1 & 1 & 1 & 0 & 139 & 91 & 0 & 0 & 0 & 0 & 0 & 0 & 0 & 0 & 0 & 0 & 0 & 0 \\
\hline 2007 & 0 & 0 & 0 & 0 & 0 & 364 & 539 & 0 & 0 & 0 & 0 & 0 & 0 & 0 & 0 & 0 & 0 & 0 & 0 \\
\hline 2008 & 0 & 0 & 0 & 0 & 0 & 130 & 381 & 0 & 0 & 0 & 0 & 0 & 0 & 0 & 0 & 0 & 0 & 0 & 0 \\
\hline
\end{tabular}

